\title{
Mechanical Properties of Wood Shavings-Cement Lightweight Composites
}

\author{
Dr. Moayad M. Kasim \\ Assist. Professor \\ Emdad K. ZEYNAL \\ Assist. Lecturer \\ Engineering College, Kirkuk University, Iraq
}

\begin{abstract}
The use of wood shavings, as a recycled waste product from the wood furniture industries is an interesting technique to produce lightweight cement composites. This study aims at examining the mechanical properties of wood shavings-cement lightweight composites. First, the wood shavings were pre-treated with water or superplasticizer or Cement Based Bitumen Emulsion (CBBE). Then, the compressive strength and tensile strength of the wood-cement matrix were experimentally evaluated. Finally, it is shown that the addition of wood shavings to cement paste gives a composite with satisfactory mechanical strengths with respect to its weight and higher toughness in addition to environmental and economic benefits.
\end{abstract}

Keywords: - compressive strength, lightweight composite, tensile strength, toughness, wood shavings.

$$
\begin{aligned}
& \text { الخواص الميكاتيكية لمركبات رقائق الخثب والسمنت خفيفة الوزن }
\end{aligned}
$$

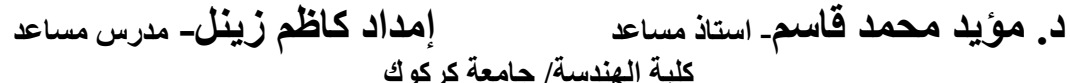

$$
\begin{aligned}
& \text { كركوك//العراق }
\end{aligned}
$$

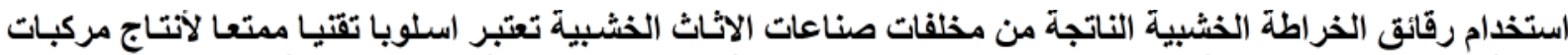

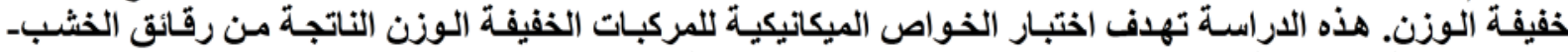

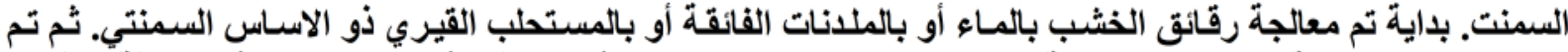

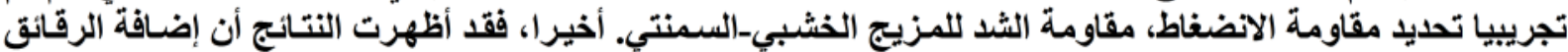

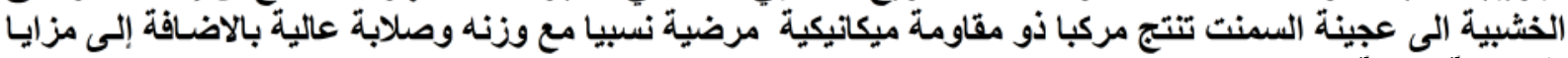
|قتصادية وبيئية. الكلمات الدالة: مقاومة الانضغاط، مركب خفيف الوزن، مقاومة الثد، الصلابة، رقائق خثبية. 


\section{INTRODUCTION}

In many countries, the wood industries generate a large amount of waste products in the worldwide. The low costs, the proximity of the sources and the potential pollution from wood wastes have led to studies into the possible use of the wood shavings as fibers in concrete. These types of materials have several potential applications such as acoustic and thermal insulation, fire resistance cladding etc. Soroushian et al. [1] reported that the flexural strength and flexural toughness values of wood fiber-cement composites were higher than the values for neat cement. In the same study, they also reported that the dynamic modulus of elasticity of neat cement decreases with increasing freezing and thawing cycles while the dynamic moduli of wood fiber-cement composites remains relatively constant over the same number of freezing and thawing cycles. Several studies mention the use of wood-ash as fillers in concrete or mortars $[2,3]$, without revealing a great improvement in mechanical properties.

Jennifer et al. [4] studied the effects of the aqueous in organic compound treatments on newspaper and Kraft fibers for enhancing some selected mechanical properties of wood fiber-cement composites. Their study indicated that certain chemical treatments react better with different wood fiber types resulting in selected mechanical property enhancement.

In another study, Soroushian and Marikunte [5] reported the effects of moisture on the flexural properties of wood fiber-cement composites. Flexural strength decreased with increasing moisture contents. In addition, dry wood fiber-cement specimens appeared to have lower flexural toughness values compared to wet wood fiber-cement specimens. Lee and Hong [6] and Blankenhorn et al. [7] used compressive strength as an indicator of wood fibercement compatibility. Lee and Hong showed compressive strength to be linearly proportional to the maximum hydration temperature, but independent of hydration time. While, Blankenhorn et al. indicated that as hydration time increased, compressive strength increases. In 1986, Rowlands et al. [8] found that strength and stiffness are increased in both tension and flexure by adding wood fiber reinforcement.

In this paper, the effects of wood/cement ratios and addition of a superplasticizers or binder emulsion with different ratios on the mechanical properties of lightweight woodcement composites were studied. The strengths, toughness, density and permeability of these composites were tested.

\section{SAMPLE PREPARATION \\ 2.1.Materials}

\subsubsection{Cement}

Locally available cement (equivalent to Ordinary Portland Cement (O.P.C.) type (I)) manufactured by Kirkuk cement Factory was used. The chemical composition of this cement is given in Table 1, while its mechanical properties are summarized in Table 2.

Table (1): Chemical composition of the used cement ${ }^{*}$

\begin{tabular}{|c|c|c|}
\hline Property & Test result, \% & Standard IQS, No.5-1984** \\
\hline \multicolumn{3}{|l|}{ 1. Oxide composition } \\
\hline Alumina, $\mathrm{Al}_{2} \mathrm{O}_{3}$ & 5.1 & \\
\hline Silica, $\mathrm{SiO}_{2}$ & 21.89 & \\
\hline Ferric Oxide, $\mathrm{Fe}_{2} \mathrm{O}_{3}$ & 3.4 & \\
\hline Lime, $\mathrm{CaO}$ & 63.11 & \\
\hline Sulphate Anhydride, $\mathrm{SO}_{3}$ & 2.22 & Max. $2.8 \%$ \\
\hline Magnesia, MgO & 3.04 & Max. 5\% \\
\hline \multicolumn{3}{|l|}{ 2. Compound composition } \\
\hline $\mathrm{C}_{3} \mathrm{~A}$ & 7.77 & \\
\hline $\mathrm{C}_{2} \mathrm{~S}$ & 29.00 & \\
\hline $\mathrm{C}_{3} \mathrm{~S}$ & 45.03 & \\
\hline $\mathrm{C}_{4} \mathrm{AF}$ & 10.34 & \\
\hline
\end{tabular}

* Manufacturer analysis

**IQS-Iraqi quality standard No.5. 
Kasim: Mechanical Properties of Wood Shavings-Cement Lightweight Composites

Table (2): Physical properties of the used cement ${ }^{*}$

\begin{tabular}{|l|c|c|}
\hline \multicolumn{1}{|c|}{ Property } & Test result & Standard IQS, No.5-1984** \\
\hline Specific surface "Blaine" $\mathrm{m}^{2} / \mathrm{kg}$ & 334.8 & 230 \\
\hline Initial setting time, min. & 150 & Min. 45 minutes \\
\hline Final setting time, min. & 245 & Max. 10 hours \\
\hline Compressive strength, MPa. & 26.79 & $15 \mathrm{MN} / \mathrm{m}^{2}$ \\
\hline At 3 days & 36.21 & $23 \mathrm{MN} / \mathrm{m}^{2}$ \\
\hline At 7 days
\end{tabular}

* Manufacturer analysis

** IQS-Iraqi quality standard No.5.

\subsubsection{Wood shavings}

White wood (almost Pine wood) shavings, a furniture industrial waste product, display a continuous grading between 5 and $60 \mathrm{~mm}$ length, 5 to $25 \mathrm{~mm}$ width, and about $0.5 \mathrm{~mm}$ thickness. The fibrous nature of the shavings is shown in Figure 1. The wood-shavings soaked with superplasticizer solution is shown in Figure 1(a) before mixing with cement and shown in Figure 1(b) after mixing with cement powder. The capillary network in wood, which allow liquid circulation, is responsible for hydrophilic nature of wood. Tamba and co-workers [9] proposed saturation of the wood shavings with water. It is kwon when cement mixed directly with wood shavings, the water available for hydration of cement could be limited due to immigration of water into the wood particles. The kinetic of water absorption is estimated as $260 \%$ of wood shavings weight after 30 minutes saturation with water according to ASTM D4442-92 [10].

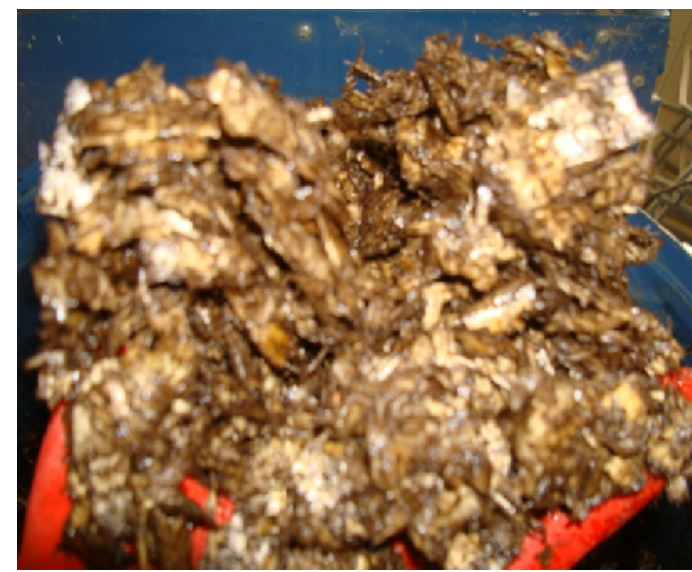

(a)

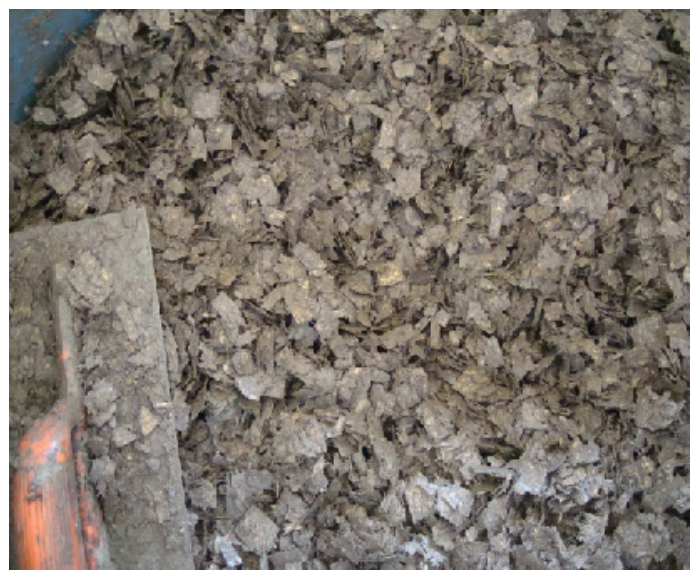

(b)

Fig. (1): The wood-shavings: (a) soaked with superplasticizer solution, (b) after soaking mixed with cement.

\subsection{Saturation Treatment}

As stated in 2.1.2 previously, Tamba et al. [9] indicated that wood shavings must be saturated with water before mixing with cement in order to achieve adequate moisture for hydration of the cement. However, to improve the interface bond between cement and wood, the workability of the matrix, and the hardness of the final product, two types of solutions were prepared and used. The first was water-superplasticizer and the second water-CBBE emulsion solutions. The properties of the added superplasticizer and the silane are shown in Table 3. The concentrations of the solutions are presented in Table 4. The wood shavings were immersed in one of these solutions for 30min. prior to their use in wood shave-cement composite. 
Table (3): Properties of the Superplasticizer and the CBBE emulsion

\begin{tabular}{|l|l|}
\hline a) Superplasticizer \\
\hline Trade name & Sikament RMC-219 \\
\hline Type & Modified polymer based liquid \\
\hline Colour & Brown liquid \\
\hline Density & $1.15-1.19 \mathrm{~kg} / 1$, at $20^{\circ} \mathrm{C}$ \\
\hline Dosage & Recommended dosage rate is between $0.5 \%$ and $1.5 \%$ by weight of binder \\
\hline b) Cement-based & bitumen emulsion \\
\hline Trade name & Poly coat \\
\hline Type & Cement-based bitumen emulsion, cold applied \\
\hline Density, $\mathrm{kg} / \mathrm{m}^{3}$ & 1600 \\
\hline Colour & Grey-black \\
\hline
\end{tabular}

\subsection{Specimens Preparation}

Cementitious composite samples 100x100x100 mm cubes were manufactured using a mix of cement, wood shavings and water. The wood/cement ratio varied in these tests as given in Table 4. Cement was added on wet saturated wood shavings and mixed in a pan mixer following ASTM C 305-94[11]. The water and plasticizer or CBBE-emulsion solutions were added to wood shavings and soaked for 30 minutes before mixing. The mixtures were then poured into the molds in two layers each of them subjected to $0.06 \mathrm{MPa}$ pressure forming the cube specimens [12]. The specimens were demolded after $24 \mathrm{~h}$ and placed in limewater bath and continued to cure for an additional 27 days. The temperature of the water bath was ranged $\left(23+1.7^{\circ} \mathrm{C}\right)$ in accordance with ASTM C 192 / C192M-98[13]. The samples were taken out from the curing tank and conditioned in the laboratory atmosphere (about $33{ }^{\circ} \mathrm{C} \& 43 \% \mathrm{RH}$ ) for 7 days to change to air-dried specimens prior the test. The compressive strength and split tensile strength tests were conducted using a $3000 \mathrm{kN}$ compression testing machine type Alpha. These tests were conducted according to BS 1881: 116: 1983 [14] and BS 1881: 117: 1983 [15]. The equilibrium air-dried density and normalized toughness were tested following the ASTM C567-05a [16] and ASTM D5873-14 [17].

Table (4): Mixture proportions used in investigation

a) Samples treated with Sika Superplasticizer

\begin{tabular}{|l|c|c|c|c|c|c|}
\hline \multirow{2}{*}{ Sample } & \multirow{2}{*}{$\begin{array}{c}\text { Cement/wood } \\
\text { Ratio }\end{array}$} & $\begin{array}{l}\text { Superplasticizer } \\
\text { /Cement } \\
\text { percentage (\%) }\end{array}$ & \multicolumn{4}{|c|}{ Percentage of components weight (\%) } \\
\cline { 4 - 7 } & 1.0 & 0.0 & 21.69 & 21.69 & 56.62 & 0.00 \\
\hline AS & 1.0 & 1.0 & 21.69 & 21.69 & 56.40 & 0.22 \\
\hline AS-1 & 1.0 & 1.5 & 21.62 & 21.62 & 56.44 & 0.32 \\
\hline AS-2 & 1.0 & 2.0 & 21.64 & 21.64 & 56.29 & 0.43 \\
\hline AS-3 & 1.5 & 0.0 & 29.35 & 19.57 & 51.08 & 0.00 \\
\hline BS & 1.5 & 1.0 & 29.35 & 19.57 & 50.79 & 0.29 \\
\hline BS-1 & 1.5 & 1.5 & 29.23 & 19.48 & 50.85 & 0.44 \\
\hline BS-2 & 1.5 & 2.0 & 29.18 & 19.46 & 50.78 & 0.58 \\
\hline BS-3 & 2.333 & 0.0 & 39.25 & 16.83 & 43.92 & 0.00 \\
\hline CS & 2.333 & 1.0 & 39.26 & 16.83 & 43.52 & 0.39 \\
\hline CS-1 & 2.333 & 1.5 & 39.28 & 16.84 & 43.29 & 0.59 \\
\hline CS-2 & 2.333 & 2.0 & 39.21 & 16.80 & 43.21 & 0.79 \\
\hline CS-3 & & & & & & \\
\hline
\end{tabular}


b) Samples treated with CBBE emulsion

\begin{tabular}{|c|c|c|c|c|c|c|}
\hline \multirow{2}{*}{ Sample } & \multirow{2}{*}{$\begin{array}{c}\text { Cement/Wood } \\
\text { Ratio }\end{array}$} & \multirow{2}{*}{$\begin{array}{c}\text { CBBE emulsion/ } \\
\text { Cement percentage (\%) }\end{array}$} & \multicolumn{3}{|c|}{ Percentage of components weight (\%) } \\
\cline { 4 - 7 } & 1.5 & 15 & 28.93 & 19.29 & 47.44 & 4.34 \\
\hline BF-15 & 1.5 & 25 & 28.66 & 19.10 & 45.07 & 7.17 \\
\hline BF-25 & 1.5 & 35 & 28.38 & 18.93 & 42.76 & 9.93 \\
\hline BF-35 & 1.5 & 50 & 27.99 & 18.65 & 39.37 & 13.99 \\
\hline BF-50 & \multicolumn{1}{|l}{ emulsion } \\
\hline
\end{tabular}

\section{RESULTS and DISCUSSION}

It was difficult to ascertain average mechanical properties values between different treatment levels and types due to the following reasons:

1. Wood shavings being a biological material had inherent variability in chips size and properties;

2. The distribution of wood shavings and direction of fibers in the matrix of specimens in relatively small sample had a statistical effect;

3. The difficulties to keep the entire depth of the specimens pressed under a certain pressure without adding any accelerator to accelerate the setting of the cement;

4. The intensive lightweight and large pores in microstructure of the hardened matrix gives a trend to different test results.

The observations of Figure 2 show the fibrous nature of the wood, which allows accommodating the deformations and provides good adhesive on the matrix.

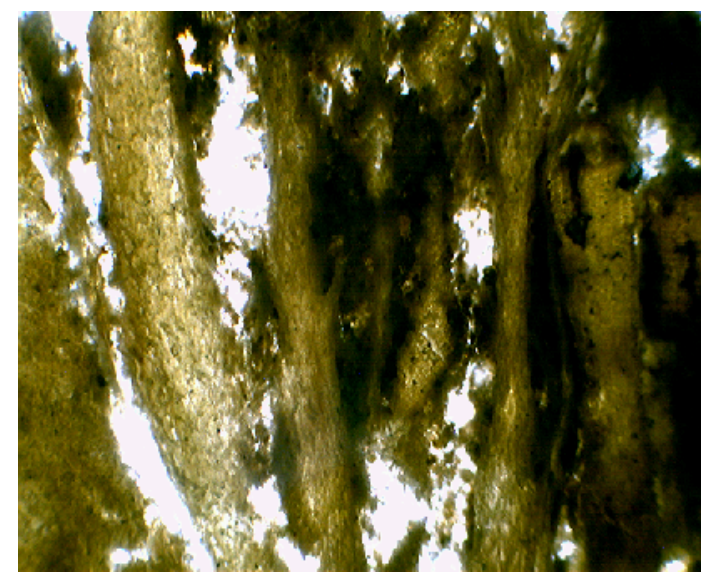

(a)

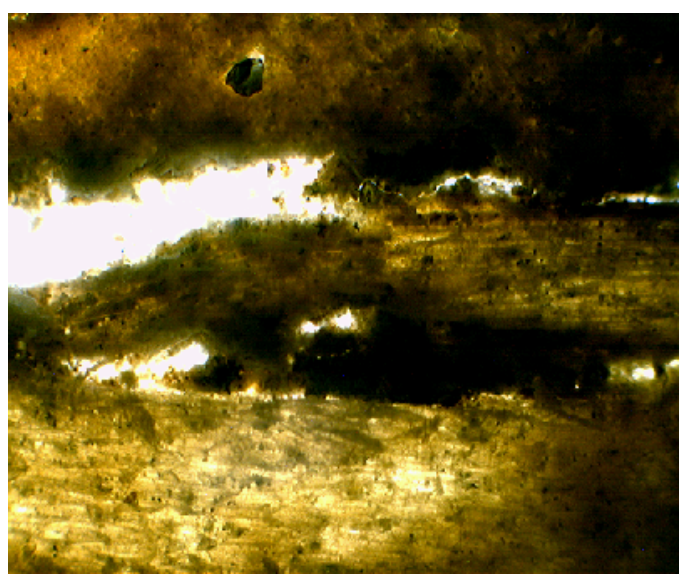

(b)

Fig. (2): Polarized electronic microscopy images of a BF sample (40 x): (a) parallel to load shaving surface and cement matrix, (b) perpendicular to load shaving surface.

\subsection{Wood-cement Composites Treated with Superplasticizer}

The average compressive strength, indirect tensile strength, equilibrium air-dried density and normalized toughness for the untreated and treated with superplasticizer wood shavingscement composites were presented in Table 5. In general the results of compressive and indirect tensile strengths for untreated composites were slightly higher than most levels of superplasticizer treated wood shavings-cement composites. The composite BS-1 has 10\% increase in compressive strength and $34 \%$ in indirect tensile strength, while CS- 1 has only $12 \%$ increase in indirect tensile strength compared with strengths of untreated specimens. 
The marginal improvement in compressive and tensile strengths of treated woodcement composites with superplasticizers may be attributed to two reasons: a) the weak interfacial bond between fibers and cement paste due to the smoothened surface characteristics of the wood shavings due to saturation treatment, b) the decrease of effective $\mathrm{w} / \mathrm{c}$ ratio needed for hydration of the cement and increase in free $\mathrm{w} / \mathrm{c}$ ratio. The strength of the bond between wood fiber and cement determines the composite properties and depends on the wood species, fiber treatment, and additives in the mixture [6].

However, this treatment of the wood-cement composites had increased the density for groups $\mathrm{AS}, \mathrm{BS}$ and $\mathrm{CS}$ specimens up to $25 \%$ and $33 \%$ respectively and the average normalized toughness values had increased for specimens AS, BS and CS up to $58 \%, 95 \%$ and $100 \%$ respectively. These increases in density and enhancement in toughness may be explained by decreasing the voids space per unit volume and increasing in cement/wood ratio.

\subsection{Wood-cement Composites Treated with CBBE Emulsion}

The average compressive strength, indirect tensile strength, equilibrium air-dried density and normalized toughness for the untreated and treated with CBBE emulsion wood shavingscement composites were presented in Table 6. Comparing the wood-cement composites treated with $\mathrm{CBBE}$ emulsion and that treated with Superplasticizer, their mechanical properties produce some interesting results. The average of relative compressive strength and tensile strength per specimen density were higher when treated with CBBE emulsion by about $6 \%$ and $3 \%$, respectively.

However, all of the treated wood-shavings average compressive strength and tensile strength values were lower than the untreated values except for the treated composite BF-50, which shows a $10 \%$ increase in compressive strength.

\subsection{Permeability of Specimens}

The permeability determination of wood-cement composites was tried according to the United States Bureau of Reclamation Procedure [18]. Performing a water-tighten acrylic sealant cover over the specimens cubes was failed due to the difficulties in cleaning the wood dust and the oil from specimens surfaces and so a weak bond produced between the silicone and wood-cement composites. However, a high permeability was observed in this type of composites.

\section{Conclusions}

For most of the measured properties, the lower percentage treatment agent shows better properties for wood-cement composites when treated by superplasticizer, while composites treated with CBBE emulsion have higher average values at higher percent levels.

The test results indicate that a lightweight mortar having equilibrium air-dried density less than $840 \mathrm{~kg} / \mathrm{m}^{3}$ and compressive strength above $3.2 \mathrm{MPa}$, except for AS-2 is $2.55 \mathrm{MPa}$, can be produced.

According to the compressive strength criteria, the specimens with cement/wood ratio of 2.0 have best results than the lower cement/wood ratios of 1.5 and 1.0 for all specimens treated in various levels. 
Table (5): Strength properties and density of wood-cement composites treated with superplasticizer

\begin{tabular}{|l|c|c|c|c|}
\hline Samples & $\begin{array}{c}\text { Compressive strength } \\
(\mathrm{MPa})\end{array}$ & $\begin{array}{c}\text { Indirect tensile } \\
\text { strength }(\mathrm{MPa})\end{array}$ & $\begin{array}{c}\text { Equilibrium air-dried } \\
\text { density }\left(\mathrm{kg} / \mathrm{m}^{3}\right)\end{array}$ & $\begin{array}{c}\text { Normalized } \\
\text { toughness }\end{array}$ \\
\hline AS & 4.19 & 0.4 & 440 & 1.00 \\
\hline AS-1 & 3.76 & 0.27 & 480 & 1.58 \\
\hline AS-2 & 2.55 & 0.16 & 550 & 1.58 \\
\hline AS-3 & 3.38 & 0.24 & 520 & 1.54 \\
\hline BS & 3.88 & 0.35 & 550 & 1.65 \\
\hline BS-1 & 4.26 & 0.47 & 560 & 1.85 \\
\hline BS-2 & 3.2 & 0.22 & 690 & 1.95 \\
\hline BS-3 & 4.11 & 0.26 & 610 & 1.86 \\
\hline CS & 5.97 & 0.58 & 630 & 1.81 \\
\hline CS-1 & 4.41 & 0.65 & 740 & 1.97 \\
\hline CS-2 & 3.41 & 0.32 & 840 & 2.00 \\
\hline CS-3 & 5.42 & 0.32 & 670 & 1.96 \\
\hline
\end{tabular}

Table (6): Strength properties and density of wood-cement composites treated with CBBE emulsion

\begin{tabular}{|l|c|c|c|c|}
\hline Samples & $\begin{array}{c}\text { Compressive } \\
\text { strength (Maps) }\end{array}$ & $\begin{array}{c}\text { Indirect tensile } \\
\text { strength (MPa) }\end{array}$ & $\begin{array}{c}\text { Equilibrium air-dried } \\
\text { density }\left(\mathrm{kg} / \mathrm{m}^{3}\right)\end{array}$ & $\begin{array}{c}\text { Normalized } \\
\text { toughness }\end{array}$ \\
\hline BF-0 & 3.88 & 0.35 & 550 & 1.65 \\
\hline BF-15 & 3.14 & 0.23 & 550 & 2.04 \\
\hline BF-25 & 3.48 & 0.34 & 540 & 2.04 \\
\hline BF-35 & 3.76 & 0.26 & 570 & 1.93 \\
\hline BF-50 & 4.28 & 0.34 & 560 & 1.73 \\
\hline
\end{tabular}

\section{REFERENCES}

[1] Soroushian P., Marikunte S., Won J.-P., "Wood fiber reinforced cement composites under wetting - drying and freezing - thawing cycles", Journal of Materials in Civil Engineering 6 (4), 1994, pp. 595-611.

[2] Naik T.R., Kraus R.N., "Use of industrial products in cement based materials", Proceeding of the International Congress 'Creating with Concrete'. Dundee, UK, Book 'Exploiting Waste in Concrete', 1999, pp. 23-35.

[3] Fehrs JE., "Ash from the combustion of treated wood: characterization and management options", National bio-ash utilization conference, Portland, 1996.

[4] Jennifer L.P., Paul R.B., Michael R.S., "Wood fiber surface treatment level effects on selected mechanical properties of wood fiber-cement composites", Cement and Concrete Research 34, 2004, pp. 59-65.

[5] Soroushian P., Marikunte S., "Moisture effects on flexural performance of wood fibercement composites", Journal of Materials in Civil Engineering 4 (3), 1992, pp. 275-291.

[6] Lee A.W.C., Hong Z., "Compressive strength of cylindrical samples as an indicator of wood-cement compatibility”, Forest Product Journal, 36 (11/12), 1986, pp. 87-90.

[7] Blankenhorn P.R., Labosky Jr. P., DiCola M., Stover L.R., "Compressive strength of hardwood-cement composites”, Forest Products Journal, 44(4), 1994, pp. 59-62. 
[8] Rowlands R.E., Van Deweghe R.P., Laufenberg T.L., Frueger G.P., "Fiber-reinforced wood composites", Wood Fiber Sci. 18 (1), 1986, pp. 39-57.

[9] Tamba S., Jauberthie R., Lanos C., Rendell F., "Lightweight wood fiber concrete", Concrete Sci Eng. 3:53-7, 2001.

[10] ASTM D444-92, "Direct Moisture Content Measurement of Wood and Wood-Base Materials". ASTM designation, 2003, p. 195.

[11] ASTM C305-06,"Standard practice for Mechanical Mixing of Hydraulic Cement Pastes and Mortars of Plastic Consistency", American society for testing and materials, Philadelphia, United States, 2006.

[12] Coutts R.S.P. and Warden P.G., "Effect of compaction on the properties of air-cured wood fiber reinforced cement", Cement and concrete composites, Vol. 12, Issue 3, 1990, pp. 151-156.

[13] ASTM C192/C192M-06,"Standard Practice for Making and Curing Concrete Test Specimens in the Laboratory", American society for testing and materials, Philadelphia, United States, 2006.

[14] BS 1881: Part 116: 1983, Method for determination of compressive strength of concrete cubes.

[15] BS 1881: Part 117: 1983, Method for determination of tensile splitting strength.

[16] ASTM C567-05a, "Standard Test Method for Determining Density of Structural lightweight Concrete", American society for testing and materials, Philadelphia, United States, 2005.

[17] ASTM D5873-14, "Standard Test Method for Determining of Rock Hardness by Rebound Hammer Method", American society for testing and materials, Philadelphia, United States, 2014.

[18] U.S. Bureau of Reclamation, 4913-92, "Procedure for water permeability of concrete", Concrete Manual, Part 2, 9th Ed., Denver, Colorado, 1992, pp. 714-25. 